\title{
Evaluation of Newly Released Common Bean Varieties through On-Farm Demonstrations in ATJK and Shalla Districts of Oromia Regional State, Ethiopia
}

\author{
Fistum Miruts*, Gemechu Gadissa, Belay Roba \\ Ethiopian Institute of Agricultural Research, Melkassa Agricultural Research Center
}

*Corresponding Author: Fistum Miruts, Ethiopian Institute of Agricultural Research, Melkassa Agricultural Research Center

\begin{abstract}
The study was conducted in Adami Tulu Jedo Kombolcha (ATJK) and Shalla districts of Oromia regional state, Ethiopia during 2016-2017 cropping season. The objectives of the study were to evaluate the newly released improved common bean varieties (SER-125 and SER-119) with their production technologies in farmers' fields by comparing them with the existing variety called Nasir. A total of 32 interested farmers were purposively selected and hosted the demonstrations. The improved common bean varieties SER-125 and SER-119 performed well and have given a mean yield of $2715 \mathrm{~kg} / \mathrm{ha}$ and $2945 \mathrm{~kg} / \mathrm{ha}$ respectively. The existing variety has given a mean yield of $2235 \mathrm{~kg} / \mathrm{ha}$. The improved varieties had yield advantage over the control. The highest yield increment (770 kg/ha) was recorded by SER-119 variety with a $36.15 \%$ yield advantage over the control (Nasir) and the lowest yield increment was $360 \mathrm{~kg} / \mathrm{ha}$ with a $15.38 \%$ yield advantage by SER-125. The utilization of improved varieties under on-farm demonstration recorded higher average gross returns (22382 birr/ha) and net returns (12923 birr/ha) compared to control plot average gross returns (16986 birr/ha) and net returns (8733 birr/ha). Therefore, the office of agriculture of the respective districts should further popularize to a large number of farmers in similar areas. Seed producer enterprise, cooperatives or organized seed producer farmers groups should continuously and consistently multiply and supply the seeds of this variety so that there is sustainable seed supply for SER-119 and SER-125 varieties in the area.
\end{abstract}

Keywords: Common Bean, Demonstration, Improved, Varieties

\section{INTRODUCTION}

In Ethiopia, agriculture is the leading sector which contributes to nearly $34 \%$ of the country's gross domestic product (GDP) and $71 \%$ of employment. Crop production makes up $72 \%$ percent of the total agricultural GDP, of which cereals production covered $79.9 \%$, pulses $13.2 \%$ and oil seeds $6.9 \%$. (ATA, 2018).

Common bean (Phaseolus vulgaris L.) is one of the most important pulse crops grown in Ethiopia in terms of both area and quantity produced. The crop is cultivated in different parts, mainly Oromia, Amhara and Southern Nations Nationalities and Peoples Region (SNNPR). Their share of the national common bean production is $51 \%$ for Oromia, $24 \%$ for Amhara and 21\% for SNNPR (CSA, 2018). Almost all common beans are produced under rainfed conditions by smallholder farmers on less than 0.5 hectares (Ephrem, 2016). The crop is one of the most important cash crops and sources of protein for farmers in many lowlands and mid-altitude zones. It is also widely intercropped with maize and sorghum to supplement farmers with additional income and to maintain soil fertility (IBC, 2012). Common bean farmers preferred the crop because of its fast maturing characteristics that enable households to get cash income required to purchase food and other household needs when other crops have not yet matured (Berhanu et al., 2018).

The area under common bean production in Ethiopia during 2007/2008 was 231,443.06 hectares rose to nearly $306,186.59$ hectares in $2017 / 2018$ and the production from 2,414,176.41 quintals to $5,209,793.27$ quintals. At the same time, the number of common bean producer farmers increased from $2,147,871$ to more than $3,622,330.00$. The average productivity of the crop also increased from $10.4 \mathrm{~kg}$ per hectare to $1700 \mathrm{~kg}$ per hectare in the last ten years (CSA, 2018). 
The Ethiopian Institute of Agricultural Research (EIAR), have released and popularized a number of improved varieties (high yielding, early maturity and disease resistant, varieties meeting the requirements for local consumption and export markets) and management practices since early 1960s to enhance the productivity of common bean and income. However, due to the availability of high yielding varieties, suitable production environment and economic and food security importance of the crop, the actual smallholder farm yields $(1700 \mathrm{~kg}$ per hectare $)$ are by far below the potential yield (3500 kg per hectare) at research stations and $3000 \mathrm{~kg}$ per hectare for research managed farmers field (MoANR, 2016; Zerihun, 2017; Berhanu et al., 2018).

Table1. Common bean varieties released between 2011 and 2015

\begin{tabular}{|c|c|c|c|c|c|}
\hline $\begin{array}{c}\text { Name of } \\
\text { Variety }\end{array}$ & Altitude (m) & Seed color & \multicolumn{2}{|c|}{ Productivity (Kg/ha) } & \multirow{2}{*}{ Year of release } \\
\cline { 4 - 5 } $\begin{array}{c}\text { SAB 736 } \\
\text { (Ado) }\end{array}$ & $1450-2000$ & Large White & $2000-2500$ & $1800-2200$ & 2015 \\
\hline $\begin{array}{c}\text { SAB 632 } \\
\text { (Tafach) }\end{array}$ & $1450-2000$ & Speckled & $2200-2600$ & $1900-2400$ & 2015 \\
\hline SER-119 & $1450-2000$ & Red & 3300 & 2500 & 2014 \\
\hline SER-125 & $1450-2000$ & Red & 3500 & 2200 & 2014 \\
\hline $\begin{array}{c}\text { Dendesu } \\
\text { (KAT B9) }\end{array}$ & $1300-1650$ & Red & $2200-3000$ & $1900-2300$ & 2013 \\
\hline $\begin{array}{c}\text { Adda } \\
\text { (KATB1) }\end{array}$ & $1300-1650$ & Yellow & $1900-3300$ & $1700-2500$ & 2013 \\
\hline Awash-2 & $1450-2000$ & White & $2800-3100$ & $1800-2200$ & 2013 \\
\hline $\begin{array}{c}\text { Morka } \\
\text { (ECAB- } \\
\text { 0056) }\end{array}$ & $1400-2200$ & Red mottled & 2500 & 2000 & 2012 \\
\hline GLP-2 & $1400-2200$ & Red mottled & 3000 & 2200 & 2011 \\
\hline
\end{tabular}

Source: Berhanu et al., (2018); MoANR, (2016)

According to Amanuel and Girma (2018), the low national yield is related to the low adoption of improved production technologies, lack of improved varieties and poor cultural practice. Yetayal and Lema (2019), also reported disease and pest, drought, poor availability and the high price of improved seed and unstable product price are major constraints of common bean production. The objective of this study, therefore, is to demonstrate the newly released improved common bean varieties (SER-125 and SER-119) with their production technologies in farmers' field, evaluate and select the best-fit variety for future large-scale technology demonstration and popularization.

\section{Materials AND Methods}

\subsection{Description of the Study Area}

ATJK district is one of the districts of East Showa Zone of Oromia Regional State, bordered by Dugda district to North and Arsi Negelle district from South while Zuway Dugda district from East and SNNP regional state is from West. It is found at $168 \mathrm{~km}$ South of Addis Ababa with total area of $140,324.6 \mathrm{~km}^{2}$. The area receives mean annual rainfall of $690 \mathrm{~mm}$ and it has an altitude between 1500 and 2300 meters above sea level (Bezabeh et al., 2010; EEPCo, 2013). The major economic sectors of the district are crop production, animal husbandry, and fishery. The main crops produced are a maze, common bean, teff and wheat (Jemila, 2014).

Shalla district is one of the districts of West Arsi Zone of Oromia Regional State, bordered by Siraro district to South, on the west by the SNNP Region, on the north by Shalla Lake, and on the east by Shashamane, its western boundary is defined by the course of the Bilate river. It is found $279 \mathrm{~km}$ south of Addis Ababa with total area of 140,324.6 km2.The area receives annual rainfall ranging from 1000 to $1200 \mathrm{~mm}$ and the main growing season (rainy season) is from June to September. The altitude of the district is estimated to be in the range between 1000 and 2300 meters above sea level. The mean annual temperature of the district lies between $22^{\circ} \mathrm{C}$ and $25^{\circ} \mathrm{C}$. Agriculture is the primary economic activity and about $95 \%$ of the population engaged. The major crops produced in the district are maize, wheat, common bean and teff (Ahmed, 2018). 


\subsection{Farmers Selection and Demonstration Field Establishment}

For the study, two kebeles from each district, Anono Shisho and Oda Anshura from ATJK district and Awara Gama and Funde Ejerso kebeles from Shalla district were purposively selected based on their accessibility and potential to common bean production. From the four kebeles, a total of 32 common bean producer farmers were selected to host the demonstration based on their interest in the common bean technology, willingness to manage and allocate field trial for the activity and willingness of collaboration with extension agents and researchers. For the demonstration full technology packages of common bean were provided and each selected farmer encouraged to prepare about 0.25 hectare of land. The varieties (SER-125 and SER-119) that have been released from the research were cultivated side by side to demonstrate and compare their performance with the one that farmers are using (Nasir). Initially, farmers were trained about improved common bean production practices (seed rate, fertilizer rate, planting dates and protection), the improved varieties characteristics and recommended agronomic practices.

\subsection{Recommended Agronomic Practices of Common Bean Cultivation}

Farmers were advised to plough their land three times before planting common bean. Planting time depends on the onset of rainfall. Usually, when rainfall starts in mid-June, planting during late June and mid-July is recommended. It is recommended common bean to be sown in rows with a seed rate of $100 \mathrm{~kg} / \mathrm{ha}$. The spacing between rows should be $40 \mathrm{~cm}$, and seeds in the row $10 \mathrm{~cm}$ apart. In poor soil, adding $100 \mathrm{~kg} / \mathrm{ha}$ of DAP during planting is recommended. When the plants are deficient in nitrogen, they show leaf yellowing, at this moment, 50-100 kg urea could be applied as top dressing before flowering. Hand weeding should be done twice. Accordingly, farmers should undertake the first hand weeding two weeks after planting, and the next weeding five weeks after sowing. To control most important yield-reducing diseases, such as bacterial blight, anthracnose, and rust; using clean, disease-free seeds and avoiding repeated cropping in the same field and planting diseasetolerant varieties is recommended (Teshale et al., 2008).

\subsection{Data Collection and Analysis}

The activity data were collected by the researchers directly from the field. Farmer's perception of the varieties was recorded from focus group discussion during the evaluation process. The collected data were analyzed using descriptive statistics and preference ranking based on farmers' set criteria.

\section{RESULTS AND DiSCUSSION}

\subsection{Yield Performance}

A comparison of productivity levels between the improved varieties and the control (Nasir) is shown in figure 1. Production comparison between the improved varieties (SER 125 and SER 119) and the control (Nasir) was made. Nasir was selected to be used as a control because it is the variety most commonly grown in the study areas.

The result obtained from the newly released improved common bean varieties as well as the control is described below in figure 1. From the field demonstration conducted in 32 farmers farm, the mean yield performance of common bean varieties in the ATJK district was $2700 \mathrm{~kg} / \mathrm{ha}, 2990 \mathrm{~kg} / \mathrm{ha}$ and $2340 \mathrm{~kg} / \mathrm{ha}$ for SER-125, SER-119 and Nasir respectively. The result obtained was higher than what was reported $(1580 \mathrm{~kg} / \mathrm{ha}$ ) by the district agricultural office (ATJKDoA, 2018). The result also shows a $760 \mathrm{~kg} / \mathrm{ha}$ yield increment by using only the recommended agronomic practices excluding the varieties. In Shalla district, the mean yield performance of improved common bean varieties was also found higher than that of the control $(2130 \mathrm{~kg} / \mathrm{ha})$. In addition, comparing the mean yield of the control from the demonstration and the mean of common bean productivity in the area (1626) reported by the district agricultural office (SDoA, 2018), shows an increment in $504 \mathrm{~kg} / \mathrm{ha}$ by using only improved agronomic recommendations by using the same variety. Comparing the varieties performance across locations, SER-119 and SER-125 with Nasir, the newly introduced variety (SER119 and SER-125) performed very well. The result conforms with (EIAR, 2016) and suggests the positive effects of demonstrations over the existing farmers practice towards enhancing the yield of common bean with its positive effect on crop yield. 
Evaluation of Newly Released Common Bean Varieties through On-Farm Demonstrations in ATJK and Shalla Districts of Oromia Regional State, Ethiopia

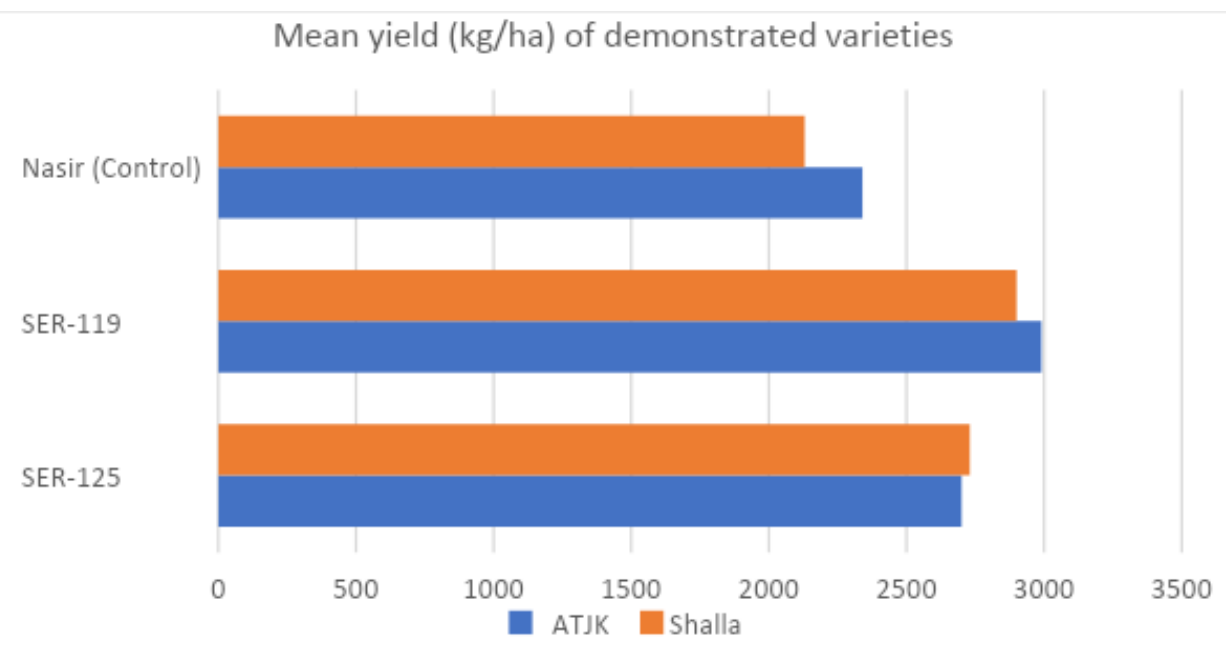

Figure1. Mean yield of varieties in ATJK and Shalla districts

\subsection{Yield Gap and Advantage}

The result of the study indicated in (Table 2) shows the recently released varieties of common bean have higher yield increment over the control in both districts. The larger yield increment was reported from Shalla district with $770 \mathrm{~kg} / \mathrm{ha}(36.2 \%)$ increment by SER-119 variety and yield increment of $600 \mathrm{~kg} / \mathrm{ha}(28.2 \%)$ by SER-125 variety over the control. In ATJK district, both the recently released improved common bean varieties have yield increment over the control with yield increment of 360 $\mathrm{kg} / \mathrm{ha}(15.4 \%)$ and $650 \mathrm{~kg} / \mathrm{ha}(27.8 \%)$ respectively for SER-125 and SER-119. Similarly, yield increment in newly released varieties of crop from demonstrations plots was documented by Gebru et. al., (2019); Fistum and Gadissa (2019); Dhaka et.al. (2015).

Table2. On-farm demonstration field yield and yield increment of common bean varieties

\begin{tabular}{|l|l|l|l|l|l|l|l|}
\hline Location & Variety & Min & Max & $\begin{array}{l}\text { Mean } \\
\text { yield }\end{array}$ & $\begin{array}{l}\text { Yield increment } \\
\text { (kg/ha) }\end{array}$ & $\begin{array}{l}\text { \% increase over } \\
\text { control }\end{array}$ & SD \\
\hline \multirow{4}{*}{ ATJK } & SER 125 & 2600.0 & 2800.0 & 2700.0 & 360.0 & 15.4 & 367.2 \\
\cline { 2 - 8 } & SER 119 & 2760.0 & 3220.0 & 2990.0 & 650.0 & 27.8 & 225.4 \\
\cline { 2 - 8 } & Nasir (Control) & 2120.0 & 2560.0 & 2340.0 & - & - & 28.2 \\
\hline \multirow{3}{*}{ Shalla } & SER 125 & 2560.0 & 2900.0 & 2730.0 & 600.0 & 36.2 & 371.1 \\
\cline { 2 - 8 } & SER 119 & 2680.0 & 3120.0 & 2900.0 & 770.0 & - & 335.1 \\
\cline { 2 - 7 } & Nasir (Control) & 2100.0 & 2160.0 & 2130.0 & - & 146.6 \\
\hline
\end{tabular}

Source: On-farm demonstration fields

\subsection{Financial Benefits}

Assessment of the profitability of common bean cultivation was calculated for every treatment using the following formula:

The profitability of common bean cultivation with the utilization of improved varieties and farmers' practices has been presented in Table 3 . The utilization of improved varieties under on-farm demonstration recorded higher average gross returns (22382 birr/ha) and net returns (12923 birr/ha) compared to control plot average gross returns (16986 birr/ha) and net returns (8733 birr/ha). These results are in conformity with the study conducted by Ndakidemi et.al., (2006) on common bean and Birhanu et.al., (2018); Afewerk and Adam, (2018) on soybeans.

Table3. Financial benefits of the improved varieties in farmers income

\begin{tabular}{|l|l|l|l|l|l|l|l|l|l|l|l|}
\hline \multicolumn{3}{|c|}{ Cost of cultivation } & \multicolumn{3}{c|}{ Gross return } & \multicolumn{3}{c|}{ Net return } & \multicolumn{3}{c|}{ Benefit cost ratio } \\
\hline Nasir & $\begin{array}{l}\text { SER- } \\
\text { SER- }\end{array}$ & $\begin{array}{l}\text { Nasir } \\
119\end{array}$ & $\begin{array}{l}\text { SER- } \\
125\end{array}$ & $\begin{array}{l}\text { SER- } \\
119\end{array}$ & Nasir & $\begin{array}{l}\text { SER- } \\
125\end{array}$ & $\begin{array}{l}\text { SER- } \\
119\end{array}$ & Nasir & $\begin{array}{l}\text { SER- } \\
125\end{array}$ & $\begin{array}{l}\text { SER- } \\
119\end{array}$ \\
\hline 8253 & 9459 & 9459 & 16986 & 20634 & 22382 & 8733 & 11175 & 12923 & $1: 23$ & $2: 18$ & $2: 37$ \\
\hline
\end{tabular}

NB: The sale price of common bean is $760 \mathrm{birr} / \mathrm{kg}$ for the year 2017-18

International Journal of Research Studies in Agricultural Sciences (IJRSAS) 
The improved variety and control plots have a positive outcome (Table 3). Being the improved varieties have positive outcomes, the farmers will be at the high-profit level if they cultivate any of the newly promoted improved varieties along with recommended agronomic practices than the control (Nasir). However, farmers will have a higher return on the amount invested in common bean farming with SER-119 variety.

\section{CONCLUSION AND RECOMMENDATION}

The study showed that the improved common bean varieties (SER-119 and SER-125) had shown better performance in grain yield than the Nasir (control). Thus, the cultivation of common bean with improved varieties has been found more productive and the yield capacity can be increased up to 36.15 percent. Replacement of Nasir variety with a newly released variety (SER-125 and SER-119) of common bean will increase the production and net income. The existing Nasir variety of common bean should be replaced with newly released common bean varieties (SER-119 and SER-125) because of higher productivity and income. SER-119 and SER-125 varieties were found to be suitable in both study locations since they fit well to the existing farming situation and also it had been appreciated by the farmers. Hence, the office of agriculture of the respective districts should further popularize to a large number of farmers in similar areas. Seed producer enterprise, cooperatives or organized seed producer farmers groups should continuously and consistently multiply and supply the seeds of this variety so that there is sustainable seed supply for SER-119 and SER-125 varieties in the area.

\section{ACKNOWLEDGEMENT}

The financial support of the Ethiopian Institute of Agricultural Research, the effort of MARC staff as well as the district and Kebele agricultural experts and participant farmers during the course of action warmly recognized.

\section{REFERENCES}

[1] Afewerk Hagos and Adam Bekele. 2018. Cost and returns of soybean production in Assosa Zone of Benishangul Gumuz Region of Ethiopia. Journal of Development and Agricultural Economics (2018) 10(11) 377-383. DOI: 10.5897/jdae2018.0952.

[2] Ahmed Kasim, Jema Haji and Lemma Zemedu. 2018. Determinants of food insecurity and coping strategies of rural households: The case of Shalla District, West Arsi Zone, Oromia Region, Ethiopia. Journal of Development and Agricultural Economics, 10(6), 200-212.

[3] Amanuel A, Girma A. 2018. Production Status, Adoption of Improved Common Bean (Phaseolus vulgaris L.) Varieties and Associated Agronomic Practices in Ethiopia. J Plant Sci Res. 2018;5(1): 178.

[4] ATA (Agricultural Transformation Agency). 2018. Agricultural Transformation Agency: Annual Report 2017-18.

[5] ATJKDoA (ATJK district office of agriculture). 2018. ATJK district annual agricultural activities report.

[6] Berhanu Amsalu, Kassaye Negash, Tigist Shiferaw, Kidane Tumssa, Dagmawit Tsegaye, Rubyogo Jean Claude, and Clare Mugisha Mukankusi. 2018. Progress of Common Bean Breeding and Genetics Research in Ethiopia. Ethiop. J. Crop Sci. Special Issue Vol. 6 No.3.

[7] Bezabih Emana, Hadcra Gcbremedhin and Nigatu Regassa. 2010. Impacts of Improved Seeds and Agrochemicals on Food Security and Environment in the Rift Valley of Ethiopia: Implications for the Application of an African Green Revolution. The Drylands Coordination Group. DCG Report No. 56.

[8] Birhanu Ayalew, Adam Bekele and Yalew Mazengia. 2018. Analysis of Cost and Return of Soybean Production Under Small Holder Farmers in Pawe District, North-Western Ethiopia. Journal of Natural Sciences Research, 8(1), 28-34.

[9] CSA (Central Statistical Agency). 2018. Agricultural Sample Survey. Report on Area and Production of major crops, Meher season. Addis Ababa, Ethiopia.

[10] EEPCo (Ethiopia Electric Power Corporation). 2013. Environmental and social impact assessment of geothermal sector development project for Aluto geothermal site development.

[11] Ephrem Terefe. 2016. Review of haricot bean value chain in Ethiopia. International Journal of African and Asian Studies, 24, 65-72.

[12] Fistum Miruts and Gadissa Ejersa. 2019. Participatory Demonstration and Evaluation of Onion Varieties in Lume and Dugda Woredas, East Shewa Zone of Oromia Regional State, Ethiopia. Journal of Natural Sciences Research. Vol.9, No.17. DOI: 10.7176/JNSR. 
[13] Gebru Brhane, Fantaye Belay, Tsegay Gebreselassie and Daniel Desta. 2019. Enhancing sorghum yield through demonstration of improved sorghum varieties in Tanqua-Abergelle Wereda, Central Zone of Tigray, Ethiopia. Journal of Agricultural Extension and Rural Development. Vol.11 (1), pp. 11-16. DOI: 10.5897/JAERD2018.1020.

[14] IBC (Institute of Biodiversity Conservation). 2012. Third country report on the state of plant genetic resources for food and agriculture, Ethiopia. October 2012, Addis Ababa, Ethiopia.

[15] Jemila Adem. 2014. Women and Indigenious Conflict Resolution Institutions in Oromia: Experience from Siinqee of the Wayyu Shanan Arsi Oromo in Adami Tullu Jiddu Kombolcha District of the Oromia National Regional State. Addis Ababa University.

[16] MoANR (Ministry of Agriculture and Natural Resource). 2016. CROP VARIETY REGISTER ISSUE No. 19. MoANR Plant Variety Release, Protection and Seed Quality Control Directorate. Addis Ababa, Ethiopia.

[17] Ndakidemi, P. A., Dakora, F. D., Nkonya, E. M., Ringo, D., \& Mansoor, H. 2006. Yield and economic benefits of common bean (Phaseolus vulgaris) and soybean (Glycine max) inoculation in northern Tanzania. Australian Journal of Experimental Agriculture, 46(4), 571-577.

[18] SDoA (Shalla district office of agriculture). 2017. Shalla district annual agricultural activities report.

[19] Teshale Assefa, Setegn Gebeyehu, Berhanu Amsalu, Kassaye Negash and Kidane Tumsa. 2008. Experiences in Common Bean Research. Addis Ababa, Ethiopia. http://www.eiar.gov.et.

[20] Yitayal Abebe and Lema Zemedu. 2019. Common Bean Production, Marketing, and Validation of New Product Concepts. Research Report No 125. http://www.eiar.gov.et.

[21] Zerihun Abebe. 2017. On-farm yield variability and responses of common bean (Phaseolus vulgaris L.) varieties to rhizobium inoculation with inorganic fertilizer rates. Journal of Animal and Plant Sciences, 32(2), 5120-5133.

Citation: Fistum Miruts. "Evaluation of Newly Released Common Bean Varieties through On-Farm Demonstrations in ATJK and Shalla Districts of Oromia Regional State, Ethiopia” International Journal of Research Studies in Agricultural Sciences (IJRSAS), 2020; 6(1), pp. 43-48, http://dx.doi.org/10.20431/24546224.0601006

Copyright: () 2020 Authors. This is an open-access article distributed under the terms of the Creative Commons Attribution License, which permits unrestricted use, distribution, and reproduction in any medium, provided the original author and source are credited. 